\title{
Morphological Patterns in \\ Eastern Anatolian Domani as a Dialect of Romani
}

\author{
DR. ÖĞR. ÜYESI ORHAN VAROL*
}

\begin{abstract}
This study aims at explaining morpho-lexical and morpho-syntactic patterns in Domani, as the two basic features related to the lexicon and grammar of this secret and endangered Romani dialect, which is also a substrate and contact language. The data was obtained by conducting face-to-face interviews with Doms living in Van and Ağr1-Doğubayazıt regions in Turkey making use of their oral narratives. The recordings between 2017 and 2019 are over 10 hours. Kurmanji, which has a typological affinity with Domani, was used as a mediating language in the communicative process. The structures exhibiting significant permeability from Kurmanji to Domani are izafe, ergative case and the light verb kirin 'to do', and its combinations. It is understood that the morpho-lexical and morpho-syntactic affixes such as $\{$-xete- $\},\{$-gev $\},\{$-ole $\}$ and $\{$-ote $\}$, which belong to Domani, lose their functionality, and continue to exist as redundant structures. On the other hand, some units such as $\{$-gi\} and \{-ge\}, function as dative and locative case markers, and in predicative domains $\{$-avi(n)\} retains some of its domain of use in Domani. Some derivational morphemes of Turkish, such as $\{-\mathrm{Iss}\}$ and $\{-\mathrm{CI}\}$ with the negation prefix of Kurmanji \{ne-\} are distinctive in the lexical formation of Domani. Compositional words consisting of different language features should be considered as 'creative languaging' for substrate language Domani, which is losing its lexical properties due to contact with superstrate languages.
\end{abstract}

Keywords: Domani, Romani dialect, morphology, multilingualism, redundancy in language

\section{BİR ROMAN LEHÇESİ OLARAK DOĞU ANADOLU DOMCASININ BIÇİMBILIMSSEL ÖRÜNTÜLERİ}

\section{Öz}

Bu çalışmada, bir alt-katman ve etkileşim dili olması yanında gizli ve tehlikedeki bir Roman lehçesi olan Domaninin sözcük-biçimsel ve biçim-sözdizimsel örüntülerini açılamak amaçlanmaktadır. Veriler, Türkiye'nin Van ve Ağrı-Doğubayazıt bölgelerinde yaşayan Domlarla yüz yüze görüşmeler ile Domca sözlü anlatılar elde edilerek sağlandı. 2017 ve 2019 yılları arasında gerçekleştirilen kayıtlar 10 saatin üzerindedir. Verilerin elde edilmesi için Domaniye tipolojik olarak benzeyen Kurmanci aracı dil olarak kullanıldı. Kurmanciden Domaniye belirgin olarak geçirgenlik sergileyen yapılar, izafe, ergatiflik ve kirin 'yap-' yardımcı eylemi ve onun bileşenleridir. Domaninin biçimsözdizimsel olarak büyük oranda Kurmanciye uyarlandığı, \{-xete-\}, \{-gev\}, \{-ole\} ve \{-ote\} gibi Domaniye ait sözcüksel ve biçim-sözdizimsel eklerinin işlevselliklerini yitirerek fazlalık yapıları olarak kaldıkları anlaşılmaktadır. Öte yandan, yüklemcil öğe üzerinde bulunabilen \{-avin\}, kalma ve yönelme durum eki gibi işlev gören $\{$-gi\} ve $\{$-ge Domanideki varlıklarını dilbilgisel işlevleriyle birlikte belirli

\footnotetext{
* Yüzüncü Y1l Ün. Edebiyat Fak. Dilbilim Böl. orhan_van@hotmail.com, orcid: 0000-0001-8662-484X 
oranlarda korumaktadır. Türkçenin $\{-\mathrm{Iş}\}$ ve $\{-\mathrm{CI}\}$ türetim ekleri, Kurmancinin $\{-$ ne $\}$ olumsuzluk öneki ile birlikte, Domcanın sözcüksel biçimlenmesinde belirleyicidirler. Farklı dillere ait bağımlı biçimbirimlerin birleşimsel organizasyonu, bir alt katman dil olan Domcanın, üst-katman dillerle etkileşiminden dolayı sözcüksel özelliklerinde kayıplar yaşadığı dönemde bile 'yaratıcı dilselleşme' uygulaması olarak değerlendirilmelidir.

Anahtar sözcükler: Domca, Romani lehçe, biçimbilim, çokdillilik, dilde fazlalık

\section{INTRODUCTION}

$\Gamma$ he Eastern Anatolia Region of Turkey was on the transition route of various cultures and their languages belonging to different language families. The region hosted these interacting languages in the past as it does today. In addition to Standard Turkish as the language of the state and regional dialects of Turkish that spread throughout the region, Kurmanji, Zazaki (Dimili), and Domani in the east and southeast, regional Arabic and Syriac (Suryani) in the southeast, and Lazuri (Laz language) in the northeast are current languages of the Eastern Anatolian sprachbund (language contact area). Domani is one of the ninety Romani dialects and the name of the language of the Eastern Anatolian Dom people. Dom is an earlier name of the Rom and Lom and Dom of India, known as low-caste commercial nomads (Kenrick, 2007; Matras, 2007; Matras, 2012). The use of Domani as a mother tongue in the past has turned into an endangered / secret language in the last decades (Varol, 2020). Doms refer to their language as Zimangevi Domani 'Dom Language', which has been heavily influenced by superstrate languages throughout Dom's nomadic and settled lives. In the case of being a contact language, to maintain its communication competence or to lose this functionality is primarily related to the duration and intensity of the interaction. Some languages like Domani, cannot preserve their mother tongue functions as (L1) in long-term and intense interactions, but they can adopt its linguistic entity to some extent due to the use of 'secret language' (Herin, 2012; Varol, 2020). Apart from being an endangered, secret and substrate language Domani is basically a language of contact. In the historical process, when the changing habitats of the Doms are evaluated, it is understood that their language, which is of Indian origin, interacted with Kurmanji, Armenian and Turkish in Anatolia, as well as Persian, as the superstrate languages in Iranian geography and with Arabic depending on the spread of the Arabs and the religion of Islam. In other words, a language of Indo-European origin interacted with Altaic, Semitic and different Indo-European languages. The effect of Kurmanji on Domani in Eastern Anatolia and Turkish on other Romani dialects in the middle and western areas of Turkey is more visible in the centuries-long interaction network. For the Eastern Anatolian Doms, first of all, the acquisition of Kurmanji and Turkish should be seen as the basic means of getting to know the dominant cultures as well as imposing themselves on them. The dimensions of this process emerge with the changing appearance of Domani, which used to be their dominant first language, but later, in the last forty years, turned into a secret language by losing its domain of use mostly to Kurmanji which is their (L1). Domani is now (L3) after Turkish (L2), in the sense of being needed and having multilingual proficiency.

Domani is a language that has few speakers and has lost most of its functionality. Therefore, the primary research questions of the study are: 1 . What are the borrowed or inherited 
morphological patterns in Domani? and 2. What are the morpho-lexical and morpho-syntactic functions of these patterns? Additionally, based on the documented narratives of Domani speakers, it is attempted to explain which of these components are redundant structures.

\section{LITERATURE REVIEW}

The concepts of morpholexical and morphosytactic are used to determine the morphological patterns associated or related with the vocabulary and grammar of the language, together with their functions. Word formation is the relations between 'morphemes' and 'signs' to create new forms by derivation, conversion and combining (Carstairs-Mccarthy, 2005, p. 5). Braun (2009, p. $6,7)$, put forward a perspective on the lexical formulation with the word-formation markers of contact languages, based on the findings of different researchers. It is claimed that in contact situations, the affixes of recepient or input languages are lost more oftenly. Braun adds that 'although there is no general consensus on the ultimate scenario of creolisation, there is a growing tendency to regard creole genesis as a complex process in which different mechanisms and different types of influence play a role'.

The de facto lexical reservoir for Eastern Anatolian Domani is Kurmanji Kurdish, as it is Arabic for Domari of Dom people living in Arab countries (Herin, 2015; Herin, 2016). However, no derivational or inflectional morphemes from Arabic have been borrowed by Northern Domari. This is, of course, due to the non-concatenative nature of Arabic morphology. Depending on language contact the borrowed morphology of both of the languages is predominantly from Kurdish and Turkish, which have a more transparent morpheme segmentation (Herin, 2020). Domani of Eastern Anatolia, presents similarities in some of the grammatical properties with its distant relative Domari. Domari, like Domani, goes through stages of losing functionality and productivity on a morphemic level. Matras (2007) states that Domari has few productive derivational morphemes. Domani derivational morphemes are also quite few and their productivity is ambigious as a result of contact stages by which functional units of substrate language are not relevant. Cech (1996, p. 68) states that the verbal paradigm separates indigenous verbs and early loanwords from late loanwords in Romani. Additionaly the loanwords as verbs, or nouns are all marked by special markers in Romani dialects. For example, Sepeides loanverb marking for the verbal stem is $\{$-din-\} or $\{$-tin-\}. It is understood that some dependent functional units in Romani languages have lost their lexical and syntactic functions despite their structural existence. That is, they stand out as redundant structures.

Redundancy has long been considered a poor property of language in both descriptive and prescriptive linguistics. But redundancy is ingrained in language, and various redundancy traits can be found in grammar, syntax, and other parts of the language. Zwart (1992) presents a lexical category theory in which the semantic and syntactic representations are very redundant (Spencer, 1998). Grammatical redundancy refers to a language's internal systematicity and rule-governed behavior in which two or more characteristics perform the same purpose. Contextual redundancy is the recurrence of nonobligatory information in a grammatical sense. This repetition entails the replication of identical or nearly equivalent information bits (Wit and Gillette 2013). Redundancy 
can not be related only to the substrate languages. In today's contemporary nation-state languages, redundancy aspects, which are considered as residual structures, may exist for different reasons.

\section{DATA AND ANALYSIS}

\subsection{Data Collection Procedures}

Data for the current study was collected from Dom speakers living in Van and Ağr1 Doğubayazit provinces of Turkey, between 2017 and 2019. There were 8 Domani speakers, 1 woman and 7 men who were all relatives and ranged in age from 40 to 55. Data was based on Doms' oral narratives, which included daily activities, stories of their nomadic life and secret language, wedding rites in which they also perform as entertainers. The topics were determined depending on the observations about the language competence of the speakers in Domani. In addition to noting the answers given about what the word and sentence equivalents are in Domani, the data was recorded with two different voice recorders for later confirmation. Extra questions were often posed to comprehend the meaning of words and the functions of grammatical elements in Domani. The data content is around 10 hours long and includes partly Kurmanji and Turkish as code mixing and code-switching languages. Kurmanji was mostly utilized by the researcher for data collection as an intermediate language that is typologically similar to Domani.

\subsection{Data Analysis}

The evaluation and analysis of the data were carried out depending on the basic determinations of morphological glossing in the lexical and syntactic contexts specified in Haspelmath (2002) and Haspelmath and Bickel (2008). It was attempted to distinguish dependent functional units in the oral corpus, which contained roughly 400 Domani-originated words. The patterns that are unique to the Domani and those that belong to the dominant languages were identified, and their utility was attempted to be comprehended. In this context, redundancy structures in Domani lexicon and grammar were also tried to be understood. Specific word building strategies of Domani were discussed. But first and foremost, the importance of developing a Domani-specific writing alphabet was underlined.

\section{MORPHOLOGICAL PATTERNS IN DOMANI}

\subsection{Writing in Domani}

Romani people could not establish a writing system, because of their unique lifestyles, traditions, and external factors such as dominant people that excluded others. The writing method used in Romani dialect studies are mainly based on Latin, incorporating specific signs, and are supplemented by the IPA. In this study, it is thought to be appropriate to adapt and implement Kurmanji for writing in Domani, as it influences the Domani in phonetic transmissions as well as other linguistic transitions. Depending on the quantity and frequency of loan elements transferred from Kurmanji into Domani, the phonemic inventory of Eastern Anatolian Domani contains all of the Kurmanji phonemes, not only in loan words or morphemes but also as inherited traits. The 
phonemes in Domani are listed alphabetically in /../ with their [IPA phonems / notations] as follows:

/a/ [a / a:] , /b/ [b], /c/ [dz], /ç/ [t], /d/ [d], /e/ [ع/ ع:], /ê/ [e:], /f/ [f], /g/ [c],/g/ [g], /1/ [ł], /i/ [i / i:], /j/ [3], /k/[k], /1/ [1 / t], /m/ [m/ m], /n/ [n / p], /o/ [o / o:], /p/ [p], /q/ [q], /r/ [r / r], /s/ [s], /ş/ []], $/ \mathrm{t} /[\mathrm{t}], / \mathrm{u} /[\mathrm{u}], / \mathrm{u} /[\mathrm{u} / \mathrm{u}:], / \mathrm{v} /[\mathrm{v}], / \mathrm{w} /[\mathrm{w}], / \mathrm{x} /[\mathrm{x}], / \mathrm{y} /[\mathrm{J}], / \mathrm{z} /[\mathrm{z}]$

Approximately four hundred words have been identified in the Domani word list alongside a few Kurmanji and Turkish origin (Varol, 2020, p. 216-222). There are no word examples containing the /ö/ [ø] sound or its variations, indicating that Turkish did not diffuse into Domani.

According to the data, there are no $/ 1 /, / \mathrm{u} /$ or $/ \hat{\mathrm{u}} /$ vowels in Domani in word initial positions, but they can be seen on the other sequential domains of the words. A distinction has been made and exhibited in both alphabet and word representation, between voiceles palatal plosive /g/ [c] givras 'clarion' and voiced unaspireted back dorsal velar stop /g/ [g] 'in Hindi /घ/' garde 'good'. The use of /i/ rather than /î/ for word representation is recommended because it is compatible with the Turkish alphabet, the other model code, and the IPA (Ergenç and Uzun, 2017). This writing approach is used to create all Domani' discourse patterns in the study.

\subsection{Domani Morphemes and Morpho-Lexical Processes}

The morphemes that have been utilized in Domani, whether inherited or conveyed via linguistic contacts, have been documented. Domani morphemes with their affixation domains and languages of source are listed in the table below:

\begin{tabular}{|l|l|l|l|l|l|l|l|}
\hline Morphemes & Prefix & Infix & Suffix & Domani & Kurmanji & Turkish & Functions \\
\hline andın & & & $\checkmark$ & & $\checkmark$ & & infinitive, (derivation) \\
\hline$(a)$ se/si & & & $\checkmark$ & $\checkmark$ & & & present \\
\hline$(a / v)$ In/in & & & $\checkmark$ & $\checkmark$ & $\checkmark$ & & $\begin{array}{l}\text { infinitive, (derivation) } \\
\text { past (plural) }\end{array}$ \\
\hline$(a v) e$ & & & $\checkmark$ & $\checkmark$ & $\checkmark$ & & imperative \\
\hline$a y i$ & & & $\checkmark$ & $\checkmark$ & & & redundancy \\
\hline$b e \hat{e}$ & $\checkmark$ & & & & $\checkmark$ & & negation \\
\hline$b \hat{e} \ldots r a$ & $\checkmark$ & & $\checkmark$ & & $\checkmark$ & & comitative \\
\hline $\mathrm{bi}$ & $\checkmark$ & $\checkmark$ & & & $\checkmark$ & & possibility (future) \\
\hline$b e j$ & $\checkmark$ & & & $\checkmark$ & & & location (in front) \\
\hline$b e r$ & $\checkmark$ & & & & $\checkmark$ & & location (behind) \\
\hline$c e v$ & $\checkmark$ & & & & $\checkmark$ & & location (next to) \\
\hline$c i / c ̧ i$ & & & $\checkmark$ & & & $\checkmark$ & derivation \\
\hline dil & $\checkmark$ & & & & $\checkmark$ & & progressive \\
\hline$e k$ & & & $\checkmark$ & & $\checkmark$ & & indefinite \\
\hline
\end{tabular}




\begin{tabular}{|c|c|c|c|c|c|c|c|}
\hline$\hat{e}, a, i$ & & & $\checkmark$ & & $\checkmark$ & & izafe \\
\hline$(y) e$ & & & $\checkmark$ & & & & copular \\
\hline gev & & & $\checkmark$ & $\checkmark$ & & & redundancy \\
\hline$g i, g e$ & & & $\checkmark$ & $\checkmark$ & & & locative, dative \\
\hline gi, ge & & & $\checkmark$ & $\checkmark$ & & & redundancy \\
\hline (s)gava & & & $\checkmark$ & $\checkmark$ & & & redundancy (adverbial) \\
\hline gavi & & & $\checkmark$ & $\checkmark$ & $\checkmark$ & & time \\
\hline go & & & $\checkmark$ & $\checkmark$ & $\checkmark$ & & time \\
\hline gol(e) & & & $\checkmark$ & $\checkmark$ & & & redundancy \\
\hline (1)se & & & $\checkmark$ & $\checkmark$ & & & imperative \\
\hline iş & & & $\checkmark$ & & & $\checkmark$ & derivation \\
\hline ke & $\checkmark$ & & $\checkmark$ & & & & negation, interrogative \\
\hline ler & & & $\checkmark$ & & & $\checkmark$ & plural \\
\hline lik & & & $\checkmark$ & & & $\checkmark$ & derivation \\
\hline$n e, n a$ & $\checkmark$ & $\checkmark$ & & $\checkmark$ & $\checkmark$ & & negation \\
\hline ole & & & $\checkmark$ & $\checkmark$ & & & redundancy \\
\hline ote & & & $\checkmark$ & $\checkmark$ & & & redundancy \\
\hline tır & & & $\checkmark$ & & $\checkmark$ & & comparative \\
\hline ule & & & $\checkmark$ & $\checkmark$ & & & redundancy \\
\hline$v i / w i$ & & & $\checkmark$ & $\checkmark$ & & & $\begin{array}{l}\text { redunduncy } \\
\text { obj.agr.) }\end{array}$ \\
\hline xetê & & & $\checkmark$ & $\checkmark$ & & & $\begin{array}{l}\text { redundancy } \\
\text { (existentiality?) }\end{array}$ \\
\hline
\end{tabular}

Table 1. The List of Domani Morphemes

Although there are chronological and proportionate disparities in Domani and Domari' linguistic connections with the dominant/model languages, Kurmanji and Turkish, they have major influences on Domani morphology. The morpho-lexical process is highlighted by three important procedures in Domani:

1. Using the inherited words of ancestral language or earlier contact languages:

minus 'man, men'; garde 'good, beautifull'; -eyd- 'come, bring'. The words in this group, rather than reflecting the core lexicon of the Domani, refer to the social status of the Doms by exhibiting patterns of secret language use. The fact that they form the terms qlor for 'police', guje for 'soldier', qerev for 'money', and veqein for 'cigarettes', which is one of the most prevalent nomenclatures in Kurmanji and Turkish, is also a reflection of identity. 
2. Using the words of contact languages with their derivational or inflectional morphemes or only the morphemes. The words and their combinations are mostly adapted to the phoneme inventory of Domani depending on the time of borrowing (the earlier the borrowing, the more likely the adaptation). Turkish beyler in Domani is used for self-appellation of Doms, most probably as a reaction to pejorative labellings of dominant societies ${ }^{1}$. The word appears as begler 'noblemen' a base form of Turkish bey 'nobleman" with the Turkish plural suffix '1Ar' borrowed together. In the last decades, the influence of Turkish on minority languages in Turkey increased, and synchronously the number of Turkish lexical items have increased in these languages as well as in Domani. There are several other loan Turkish words and suffixes in Domani. Some of these words were transferred from different languages to Turkish, and through Turkish to Kurmanci and Domani: banqa-ci 'bank-er', texsi-ci 'taksi-driver', yol-lux 'travel-needs', dur-ax 'stop' etc. Although it is of Arabic origin, it can be thought that the word sinir "nerve", which is more likely to be a unit transferred from Turkish according to the interaction network, is formed due to the integration of Kurmanji constructive suffix (-i): sinari 'angry, crabby' as manner of adverb. The absence of this word in Kurmanji and instead having its synonym, bêx $\hat{u}$ 'crabby' or bihêrs; hêrsbh 'angry', leads us to believe that the base term's source language is Turkish. Since the word sinir "nerve" was converted to the Domani phonem inventory as snar, we can assume that this is an early borrowing word. This example also demonstrates the inter-linguistic prevalence and usage of the features of Kurmanji's dependent derivational suffixes.

Kurmanji words as base form or with affixes attached could be seen in Domani as loan words or as borrowings along with their Domani equivalences. Domani words with Kurmanji infinitives: lu-kuş-andın 'to kill'; gal-çuv-andın 'speaking' bı-qıy-tır-ın 'to look over', neç-ln 'dancing', br-mengav-in 'to want'. ne-muştor 'ill'.

3. Using Domanified loan words by Domani affixes that are structurally present in Domani but have lost most or all of their semantic value. The most of the Domani morphemes seen in Domani attached to the inherited or borrowed words, as suffixes mostly have ambiguous functions. These are \{-xetê-\}: Caner-xetê 'knowing'; \{-gev\}: bêkar-gev 'single', \{-ole/-ule\}: genc-ole 'young', deng-ule 'narrow', \{-ote\}: zer-ote 'gold'. As a derivational strategy, compounding represent how the words that belong to different languages come together in Domari. By the combination of Kurmanji gis 'all' and Turkish tane 'item, piece', meaning doesn't change of the giş tane 'all' (Matras, 2009, p. 39). Although the combined term with tane has redundancy in this example, one could argue that it implicates a stress function.

As it is understood, some morphemes belonging to substrate languages lose their functionality but continue to occupy the utterance domains structurally for an uncertain period of time in the final stages of language death. The Dom speakers continued to utilize morphemic pieces that had lost their value, creating the perception that these pieces were aided in the creation of a secret language that the dominant societies couldn't grasp. Another reason for the presence of these elements in Domani is redundancy. Contact with superstrate languages caused the Domani

\footnotetext{
${ }^{1}$ The Doms of Van feel it offensive to be referred to as Qereçi, Qerqut, Çingene, or even Mitırıp, a Romani group that also lives in Van. Similar disparaging terms for Romani groups can be found in several places of the world.
} 
to lose its functions, communication settings, and linguistic characteristics, which explains why redundancy structures are much more visible in Domani. Domani provides examples of how semantic features in substrate languages have been lost before their structural appearance by having redundant morpheme structures.

Kurmanji is influenced by Turkish, which has been the dominating language in the sphere of linguistic interaction for centuries, much as Domani was influenced by Kurmanji. However, unlike Domani, dependent morphemes such as izafe and obliqe case, agreement affixes, prepositions and postpositions or pronouns and conjunctions as independent units continue to exist in the spoken Kurdish language. The borrowed linguistic elements from Turkish are generally content words placed in the spoken Kurmanji Kurdish utterance domains according to the Kurmanji morphosyntactic rules and morphemes. It should also be noted that depending on the level of competence in Kurmanji, the qualitative appearences and quantitative rates of borrowed elements may differ. The most striking dependent redundant structures in the utterances are the Turkish [mIş] morpheme, which is seen without semantic content in predicate areas with Turkish verbal nouns such as ödemiş 'paid':

Min qerê xwa öde-mîş kir 'I paid my debt'. In this utterance \{-mîş\} has no meaning but a linkage between Turkish verb öde 'pay' and Kurmanji light verb² kirin 'do'. The bilingual Kurds with better Kurmanji, can construct the predicate as ...öde kir '... paid' which is devoid of the \{-mIş\} redundancy structure, by implying language adjustments (Varol, 2017).

\subsubsection{A Derivational Strategy for the Word 'Begging'}

In contrast to inflection, the derivation has the potential to adjust the input word's word class. That is, derivation may result in word class transposition. This may appear to be a result of derivation's lexical enrichment and stylistic variation functions, which do not apply to inflection (Booij, 2006, p. 361). Discursive interculture entails the collaborative creation of a discursive common ground, as well as existing components of the common ground (Koole and Thije, 2001, p. 583). The concept of cultural apparatus has been used to this interacting structure (Rehbein, 2006). The latter assists interactants in routinizing action practices, mental structures, pattern knowledge, imagining forms, social experiences, and fixed emotional structures that are collectively modified and communicatively adapted (Thije, Rehbein and Verschick, 2012, p. 254). This organization of creative linguistics, which takes place depending on the functional linguistics perspective, is reflected in the Dom languages. Regarding the lexical derivational patterns of Domani, we encounter another application in connection with the word nevis "beggar". This appearance reveals a new word derivation with morpheme structures belonging to two different superstrate languages.

Matras (207, p. 38) indicates that $\{-1 \mathrm{~s}\}$ or iş in Domari (of Jerusalem) often creates infinitives, mangiš 'begging', from mang- 'to ask'. The Domani base form of the word and the derivational suffix on it differ structurally and semantically. The word for 'name,' 'voice,' and 'language' in

\footnotetext{
${ }^{2}$ In Uçar (2008), light verb construction is explained as verbs that don't have a particular meaning on their own, but they are used in conjunction with nouns borrowed from other languages.
} 
Eastern Anatolian Domani is menc, and all of the meanings of the word can be related to mang 'to ask' in Domari as illustrated below in (1) a.b.c:
(1) a. Menc-ê te
name-IZ 2S.OBL
'What is yor name?'
ke-ye?
what-COP.3S
b. Menc-ê xwa bilınd kır-ave
voice-IZ RFL high do.OPT.3S.ave
'Raised his voice!'
c. Minıs ewê menc-ê caner-e
man this language-OBL know-COP.3S
'The man knows this language'

The utterances in (1)a, and (1)b, give the first and second meanings of menc 'name' and 'voice', respectively, and with the Kurmanji izafe marker attached to them. In (1),c, Kurmanji oblique case occurs after menc 'language' These and other components of the three utterances all belong to Kurmanji Kurdish, which was the first and most effective model code for Domani over the past century. Kurmanji equivalent interrogative utterence for (1)a, is Navê te çîye? 'What is your name' as it has the same alignment. The linearization of the utterances in (1)b and (1)c is also compatible with Kurmanji. The content words, interrogative $\{\mathrm{ke}-\}$ and Domani suffix $\{$-ave\}, cause differences which will be evaluated in the following examples.

In Domani the synonym word for 'begging' is either neviş or negiş and the 'begger' is nevişxetê. This word has two other forms and most probably neviškar 'begger' is derived from interaction with Kurmanji and nevişci 'begger' is derived from interaction with Turkish. All three suffixes have the function creating nouns from the verbal roots. The word structure with Kurmanji $\{-\mathrm{kar}\}$ and Turkish $\{-\mathrm{ci}\}$ renders the Domani derivational suffix $\{$-xetê\} unclear, and both languages have a superstrate influence on Domani. These derivational suffixes provide an alternative to \{xetê\}, which is losing its prominence and semantic importance. In Domani there is no specific example of the use of nev- or neg- as 'to ask'. That is most probably because \{ne-\} is a negation prefix $\{-\mathrm{v}-\}$ and $\{-\mathrm{g}-\}$ are unstressed interchangable fusional consonants (Eratalay, 2021) connecting Indo-Iranian prefix $\{$ ne- $\}$ to the Turkish suffix $\{-15$ s $\}$, and the meaning of the combined word is the one who has no work 'unemployed' = 'begger'. The other form in Domari created by \{-iş\} is qayiş 'eating; food' derived from q- 'to eat' (Matras, 2009). This setup can also be associated with the previous example. To explain, the equivalent form of qey-iş in Domani qeyin 'eating' is derived from verbal form qey- 'eat-' and Kurmanji infinitive suffix $\{-\operatorname{In}\}$ in (2). Doms needed to design such innovative language applications to create a common communication universe for themselves that combined the features of multiple languages. There are different lexical constructions in Domani to support this claim. In Domani apart from išgol and işgev 'work' another form with metathesis of $\{$ iş $\}>\{s ̧ i\}$, şigole 'work' appears as a variation of $\{$ iş- $\}$ in (3) and the attached suffix $\{$-gole $\}$ has no morpho-syntactic function as its morpho-lexical appearance:
(2) Menev-ê xwa garde çê-ke
bila minis wari b1-qey-ın
food-IZ
RFL good PREP-do.2S
CONJ men women IRR-eat-3P 
'Make your food good, so that men (and) women eat it'

(3) Şi-gol-ê min he-xetê-ye

work-gol-IZ 1S.OBL EXS-xetê-COP.3S

'I have a job'

In (3), the topical subject of the nominal utterance, şigol 'work' is comprised by a metathesis item \{şi-\}and the \{-gol\} suffix. In Domani, legiş 'fight' is constituted by \{-iş\} suffix: cıhısın legişê 'to go fight'. In Turkish iş 'work' functions both as a free morpheme and $\{$-iş\} as a bound morpheme which has a derivational function as a suffix to create verbal-nouns. Turkish verbal-noun geliş 'coming' is derived from the verb gel 'come', and satıs 'selling (or the work of selling)' is derived from sat 'sell'. It appears that the $\{$-iş\} suffix is highly productive and functional by shifting domain of use, borrowed from Turkish and adapted to Domani and also Domari as a derivational suffix in the periods of language interactions. As it is known in language contact areas the discourse markers are highly borrowable elements due to their multifunctional natures. Another reason is that they are frequently used in discourse. One can claim that a construction, that functions like a bound morpheme as $\{$-iş\} with grammatical meaning and can exist as a word iş "job", is also highly borrowable. The equivalent form of (2) in Kurmanji is Şolê min heye 'I have a job' appears as a short form of Domani utterance or Domani represents long form of Kurmanji by adding $\{-\mathrm{gol}\}$ as suffix and $\{$-xetê- $\}$ as infix in this example. The morpho-syntactic construction of Domani with these extra items, and with out concrete meanings, appear as remarks of redundancy in Domani. Matras (2007, p. 39) states that the verbalising marker $\{-\mathrm{k}(\mathrm{ar})-\}$ (from kar- 'to do') is among the most productive derivation markers in Domari. It often attaches to the masdar forms of inherited verbal roots to form new verbs: mangiş kade 'they begged', from mangiş 'begging', based on mang- 'to ask'. In Domani, \{-kiravin\} is one of the most productive derivation markers too, and compound word for 'begging' is neviš kirin.

\subsection{Morpho-syntactic Patterns}

Except for the information given by native speakers about the meanings of the words in their language, the inflectional and derivational morphemes that belong to a known language are very helpful for understanding unfamiliar words or different constructions in the newly recognized language. This distinction plays an important role in understanding a language at risk of extinction and making it suitable for study. Kurmanji is one of the major cultures' languages, serving as a lingua franca with Turkish and a necessary language for Doms in many sectors of social and economic life. As a result of this obligatory relationship, Doms have awareness that Domani linguistic repertoire consists of quite a lot of Kurmanji traits. In the data collection process, one of the Domani speakers living in Van, used the following expression in Kurmanji to describe the mixed nature of their language:

Zımanê me nûvi zımanê Kurmanci nûvê zımanê Domaniye, yani zehf yaxıni heve

'Our language is half Kurmanji and half Domani, so they are very close to each other'. 
When a Kurmanji speaker overhears Domani, s/he can evaluate it as Kurmanji, especially in prosodic terms and lexical similarities. Additionaly, in terms of morpho-syntactic constructions and semantic network linkages, Domani is similar to Kurmanji in general. Inflectional patterns are the most important aspect in making this generalization. Booij (2006, p. 361) states that the derivational features in languages can also be determinant in the inflectional categories of syntax. In this context, the similarity of Domani with Kurmanji in terms of syntactic patterns can also be associated with derivational suffixes placed in Domani. Other Romani dialects or substrate languages, in Turkey interacting with Turkish also represent the same template. Not only borrowed but also most of the inherited words in these languages are articulated by Turkish inflectional morphemes, same as the utterances in Domani, which are substantially formed by Kurmanji3 ${ }^{3}$, as can be seen from the following utterance examples.

$\begin{array}{ccc}\text { (4) a. Gal.cuv-andın-a bizırık-a daha } & \text { garde-ye } \\ \text { word.say-IZ wiseman-OBL CMP } & \text { good-COP.3S } \\ \text { 'The statements of (a) wiseman is better' } & \\ \text { b. Rutevandın-ê ke rel-ase } & \text { xest-ê te? } \\ \text { sitting- OBL what get-PRS.3S } & \text { hand-IZ 2S.OBL } \\ \text { 'What do you gain by sitting (and not working)?' }\end{array}$

The morphosyntactic alignment of Kurmanji designs Domani utterances since most of the bounded or free grammatical units of Kurmanji are already diffused into Domani. There is also a Turkish free functional morpheme daha 'more' as an adverbial comparative given in (4a) $)^{4}$. Domani words make up the rest of the morpholexical units. The bound morphemes, izafe, oblique case, copular and person suffix in this noun clause all function as inflectional suffixes that belong to Kurmanji Kurdish. In (4)b, we encounter a structure that reflects the use of the present tense \{(a)se $\}$ in Domani. The other tense presentations in Domani are made with Kurmanji inflectional suffixes, as can be understood from the data.

(5) a. Ez te garde-tır xetê-me

1DIR 2OBL good-CMP xetê-COP.1S

'I'm more beautifull than you'

b. Min gur-ya xwa daha garde çe-kır-avi

1S.OBL house-IZ RFL CMP good fix-do.PST.3S-avi

'I built my house more beautifull'

$\begin{array}{llllll}\text { c. Me } & \text { arat-ê } & \text { vivi-ya } & \text { xwa } & \text { xilas } & \text { gir-avi } \\ \text { 1P.OBL } & \text { evening-OBL } & \text { wedding-IZ } & \text { RFL } & \text { finish } & \text { do.PST.3S-avi } \\ \text { 'We finished our wedding in the evening' } & & \end{array}$

The comparative suffix in Kurmanji is $\{$-tir\}, as in (5)a, and in Persian it is formed as $\{$-tar\}. Doms were under the influence of both Persians and Kurds and, under these circumstances, the

\footnotetext{
${ }^{3}$ This kind of representation in substrate languages is quite common as a result of the final stages of language contact and grammatical changes.

${ }^{4}$ Domari, spoken in northearn Syria and southern Turkey also includes Turkish superlative en and conditional marker $\{-$ sa\} (Herin, 2020, p. 493).
} 
transfer of a common linguistic item that is shared by both of the superstrate community languages is much higher. There may be emphatic phrases with the Turkish identifier daha 'more' in front of the qualifying component with the comparative suffix \{-tır\}: daha gardetır 'more beautifull'. In this example, the $\{$-xete\} structure of the Domani, which we encounter in many different lexical and grammatical planes, draws attention as a redundancy structure within the predicate domain. Because on nominal predicate, the first-person singular suffix $\{-\mathrm{im}\}$ occurs after the comparative suffix \{-tir\}, as can be seen in the Kurmanji version of this setting, Ez ji te xweşiktir im 'I'm more beautiful than you'. In Kurmanji, when the last sound of the word before the person suffix is a vowel, it should end with $\{-\mathrm{me}\}$ as in (5)a. Domani speakers stated that, without (-xete) combining sentences would be problematic. At the same time, they stated that this structure did not contain any meaning. The example in (5)b, demonstrates that Domani morpho-syntax has assumed the ergative-absolutive structure of Kurmanji with all its components except $\{\text {-avi }\}^{5}$. The agent of the sentence $m \mathrm{~mm}$ ' $\mathrm{I}$ ' is in oblique case, and the patient guri 'house' does not get a case marker as it is in absolutive case, and the complex predicate çekır 'built' agrees with the patient. In (5)b, and (5)c, $\{$-avi $\}$ is seen as a redundancy construction without any grammatical function. One of the assumptions that can be made about this structure is that $\{-a v i\}$ is a predicative clitic and is related to the objects/patients that agree with it. Therefore $\{$-avi\} may refer to vivi ya xwa. The second assumption is that these suffixes are present to express agreement suffixes such as person and tense on Domani verbs, as seen in the examples:

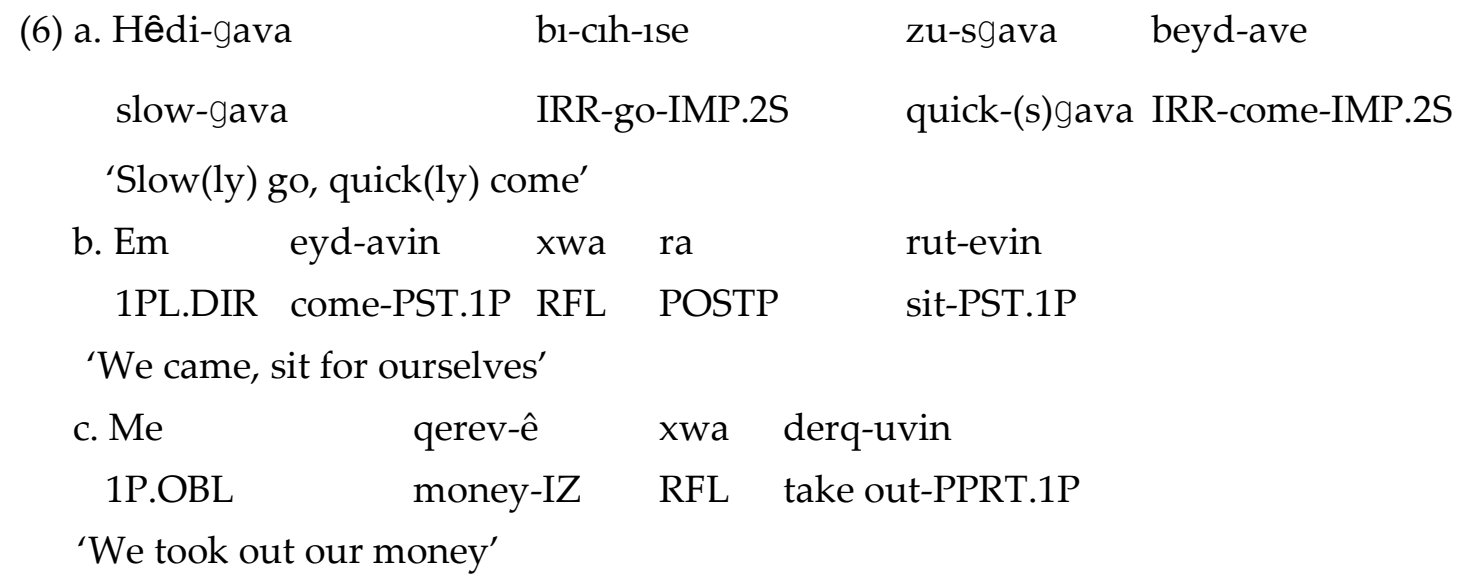

Due to language contact, both $\{-\mathrm{avi}\}$ and the Turkish evidential marker $\{-\mathrm{mIş}\}$ in bilingual Kurmanji utterances lose their function in borrowed predicate forms associated with kirin 'to do,' and both only exhibit structural presence. The predicates of the utterances in (6)a,b,c are all made with the attachments of $\{-\mathrm{AvI}\}$ variations on Domani heritage or Domanified verbs (beydave, eydavin, rutevin, derquvin), and they serve as person, mood and tense indicators. There are predicates in Domani without the $\{\mathrm{AvI}\}$ suffix: Min hınek mınıs diqi:n 'I saw some men'. In this example, the conjugated verb diq-exhibits 'see' is in past tense and $\{-$ in $\}$ is a personal suffix in the

\footnotetext{
${ }^{5}$ Ergativity patterns in Kurmanji emerge in the present tense, with the subject/agent in the absolute/direct case and the object/patient in the oblique case. Ergativity reverses its past tense alignment. The oblique case has the subject and the direct case has the object of a transitive verb and the verb agrees with the object (Aygen, 2007, p. 25).
} 
same form and function in Kurmanji. The existence of the Kurmanji inflection category can also be noted among these structures, but it would be more accurate to view them as Domanified traits, despite the fact that they are not hereditary. Kurmanji adjectives hêdi 'slow' and $z u$ 'fast, quick' emerge with Domani suffixes $\{-(s)$ gava $\}$, in (6a) it describes the way the actions take place. Kurmanji structures are laden with lexical and semanto-syntactic linkages in this setting, whereas the suffix in Domani \{-gava\} seems like a redundant structural entity. In spoken Kurmanji, the utterance in (6a) is structured in the following way: Hêdi here zu vere 'Go slow, come quick'. In other words, the adjective can be evaluated as an adverb. Reduplication is a nexus example involving morphology, phonology, and the lexicon that lends itself to a variety of theoretical methods and views. Reduplicative methods appear to be a viable alternative to evaluative affixation in expressing meaning changes. (Merlini and Dressler, 2020, p. 432). In Kurmanji, adjective structures must be transformed into an adverb with reduplication in order to become clear in syntax with all their lexical components: hêdi hêdi 'slowly'; zu zu 'quickly'. In the other model code Turkish which produces adverbials with $\{-\mathrm{cA}\}$ suffix attached to the adjectives: yavaşça 'slowly'; hızlı-ca 'quick-ly'. In this case, it's possible that the Doms express the manner in which the operation is carried out by producing an adverb with an affix \{-ava\} in Turkish, which they use as a model code. There is also reduplications in Domani, for pragmatic reasons, constitiute by the combination of these adverbial structures as echo words: hêdigava hêdigava "slowly slowly.

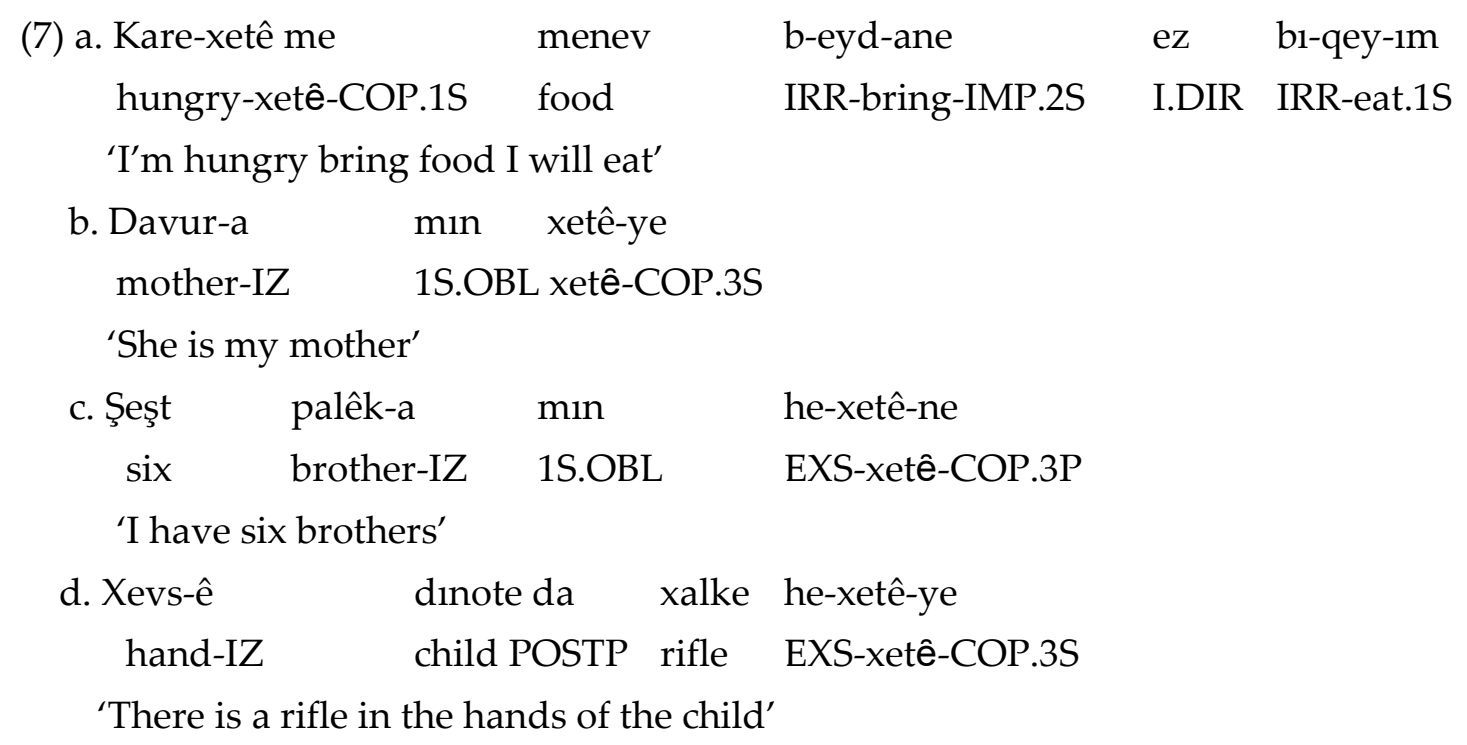

When Domani speakers converse, it is the lexical and syntactic unit $\{$-xete- $\}$ that is most heard because of its unique and dense appearance. $\{$-xetê\} can be located in most of the lexical items and in the syntax (Varol, 2020). In the syntactic structure, it is visible mostly as attached to the predicates. (7)a, is a multiple clause representation with three different predicates. The first predicate consists of $\{$-xetê\} attached to kare 'hungry' which appears as a Domani content word that can be assigned to Kurmanji first person suffix me. This can be interpreted as evidence that the redundancy rate of (-xete-) is quite high. In (7)b, \{xetê-\} is a prefix and the other sentential components before and after $\left\{\right.$ xetê-\} convey the syntactical meaning of the utterance. $(7) \mathrm{c}^{6}$, is a

${ }^{6}$ As in (7)c, Indo-Iranian number system has common characteristics in most of the Romanian languages. 
typical existential description of Kurmanji, hene 'there is' and \{-xetê-\}is inserted by the Domani speakers as an infix without any grammatical meaning. In (7)d, a similar form of predicate consists of $\{$-xete- $\}$ and again, without any function or meaning. According to the Dom speakers, $\{$-xetê-\} should always be in their utterances to link or combine the speech parts.

$\begin{array}{clll}\text { (8) a. B1 } & \text { zıman-gev-ê } & \text { Domani } & \text { gal-bi-çuv-e } \\ \text { INST } & \text { language-gev-IZ } & \text { Domani } & \text { word-OPT-do.2S }\end{array}$

'Talk in Domani language'

b. Me crhıs-ni İstanbul-ê roj-gev-i çarşem-gev-i

1P.OBL go-PPRT.1P İstanbul-OBL day-gev-OBL wednesday-gev-OBL

'We went to İstanbul on Wednesday'

Another characteristic affix that could be noticed in Domani communication is $\{$-gev\}. This suffix is mostly seen on nouns as redundancy units, like \{-xetê\}. In (8)a and b, as can be seen they are attached to the Kurmanji words, zıman and roj without loading any meaning to them. Most probably $\{$-gev $\}$ and $\{$-xetê- $\}$ were both very productive in the past and frequently used by Dom's ancestors, but they have lost their functions over time. This kind of redundancy structure can be related to the secret use of language.

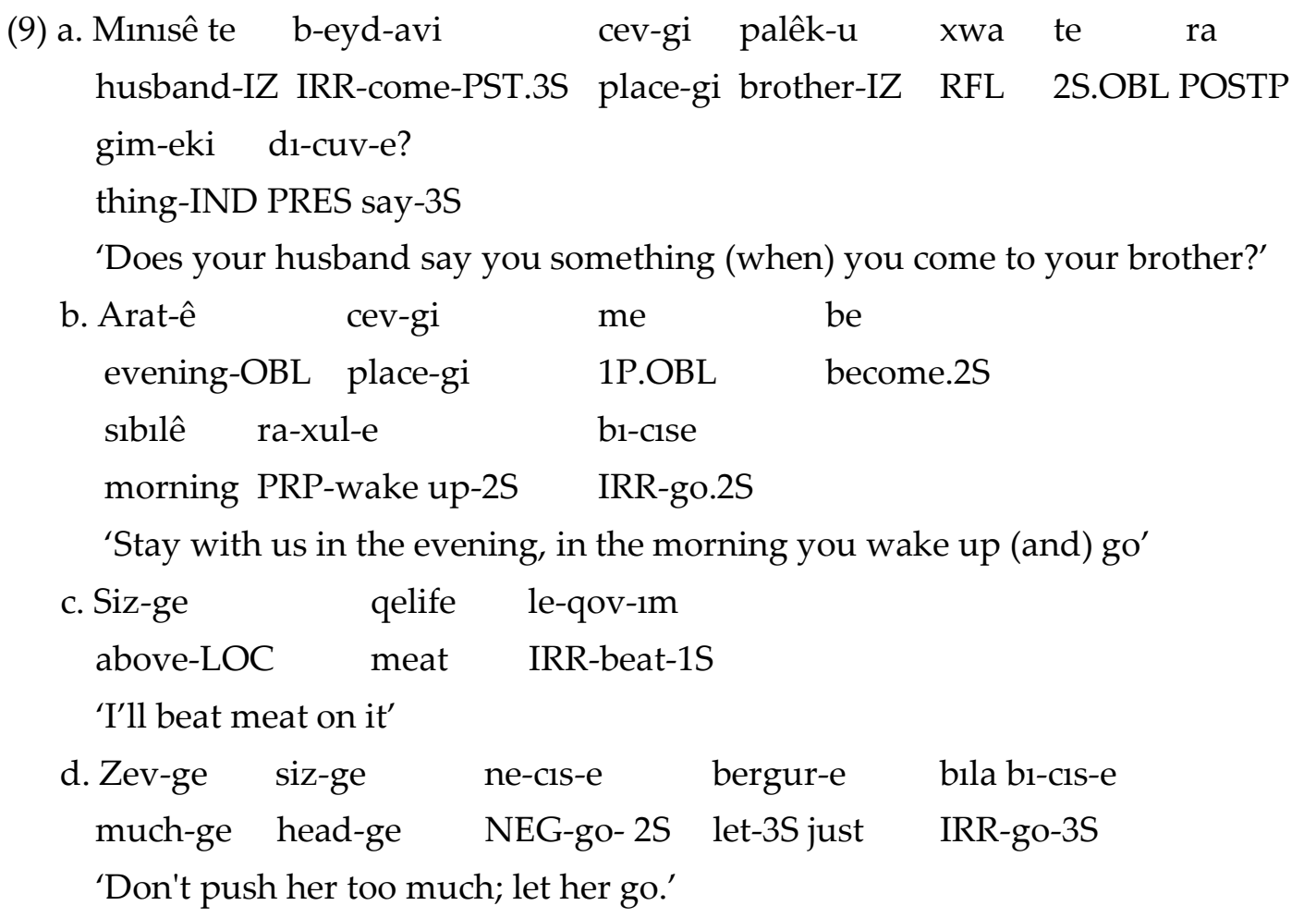

In Domani $\{$-gi/ge suffixes function as locative and dative case markers on some words as can be seen in (9)a, b, c and d. These structures, which stand out as dependent functional units that preserve the characteristics of the Domani, also question the transparency function of the oblique case of Kurmanji.
(10) Bij-gi
menev-ê
xwe b1-qey-i
before-gi food-IZ
RFL OPT-eat.PRS.2S
baj-gi gal-bı-çuv-e 
after-gi word-OPT-say-PRS.2S

'Eat before your food (and) talk after'

Another suffix seems like Domani origin, \{-gi\} serves as time adverbial bijgi 'before' and bajgi 'after' in (10), and according to the data they only emerge with these adverbials.

(11) Ew genc-ole guje-ye

this young-ole soldier-COP.3S

'This young man is a military man'

(12) Bani-yi sar-ote bi-qey-i?

water-IZ cold-ote IRR-drink-3S?'

'Do you drink cold water?'

\{-ole\} in (11) and \{-ote\} in (12) are suffixes on adjectival words and in agent and patient positions of the utterances. These structures, like $\{$-xetê\} and $\{-g e v\}$, are redundancy structures, and the outcome they confront must be the same.

\section{CONCLUSION}

The focus of this study was the questioning of the patterns with lexical and syntactic functions found in Domani utterances. There are differences between the languages that maintain their functionality and development as languages of nation-states and languages, such as Domani, under the linguistic hegemony of these nation-state languages. These differences are embedded in certain extents in the vocabulary and grammar of Domani. As a result of its socio-cultural status, interaction processes and integration consequences, Domani exhibits distinctive morpho-lexical and morpho-syntactic patterns and strategies at the final stages of its existence, associated with the changing lives of Dom speakers. Data analysis has revealed that while some of the inherited patterns in question maintain their functionality at certain rates, some stand out as the redundant structures of Domani. The suffixes $\{-x e t e-,-g e v,-o l e,-o t e\}$ are seen as redundant structures, with some exceptions, in the lexical and syntactic categories. In the syntactic structure, we see the suffixes $\{$-gi\} and $\{$-ge $\}$ containing the dative and locative cases, and the suffix $\{$ avi/n\}, which can partially exhibit the functions of specifying the person, mood and tense in the domains of predicate. Considering Domani derivational patterns and strategies determined by substratumsuperstratum relations, it is clear that the lexicalization of languages has some extraordinary dimensions, such as socio-economic divisions between societies that share the same sprachbund and lack of secret language use. Doms needed to design such innovative language applications in order to create a common communication universe for themselves that combined the features of multiple languages. It is understood that as the domain of use and frequencies of dependent functional units of the dominant language they interact with increase, and dependent functional units in their own language lose their semantic network. This inference can be made depending on the three different suffixes used in the words neviş-çi, neviş-kar and neviş-xete 'begger'. The \{-xetê\}, which is more likely to belong to the original language of Domani, is replaced by $\{-k a r\}$, which is used as a noun derivation suffix in Kurmanji, and $\{$-çi\} in Turkish, which is also used as a noun derivation suffix. Light verbs have important roles in the creation of compound verb structures. 
These structures combine with the content words of the dominant language and create new derivations in the receptive language structure and are limited to the change that occurs due to interaction. However, it is understood that these structures are permeable. According to the data, Domani acquired the light verb kirin 'to do' due to its interaction with Iranian languages and, especially, Kurmanji. The studies on evaluating the redundancy structures in the Domani and other Romani dialects at historical and comparative levels should be continued in order to understand the changes and transformations of the substrate languages.

\section{REFERENCES}

Aygen, Gülşat (2007). Kurmanjî Kurdish: Lincom Europa.

Booij, Geert (2006). "Inflection and Derivation”. Encyclopedia of Language and Linguistics, 360-369.

Braun, Maria (2009). Word-Formation and Creolisation, The Case of Early Sranan. Max Niemeyer Verlag Tübingen 002E.

Carstairs-McCarthy, Andrew (2005) "Basic Terminology", Handbook of Word Formation, Studies in Natural Language and Linguistics Theory, Ed. Pavol Štekauer, Rochelle Lieber, Springer, Netherlands.

Cech, Petra (1996). "Inflection/Derivation In Sepečides-Romani", Acta Linguistica Hungarica, 1995/1996, Vol. 43, No. 1/2 (1995/1996), pp. 67-91 Published by: Akadémiai Kiadó, URL: https://www.jstor.org/stable/44306752.

Eratalay, Süleyman (2021). "Türkçede G > V Değişimi ve /G/ Düşmesi Üzerine". [On the G > V Change and /G/ Elision in Turkish], Uluslararası Dil Edebiyat ve Kültür Araştırmaları Dergisi, 4 (1) , 141-152.

Ergenç, İclal and Pınar Uzun (2017). Türkçenin Ses Dizgesi, Ses-Ünlüler-Ünsüzler-Konuşma Organları,

[Turkish Sound System, Sound-Vowels-Consonants-Speech Organs], Seçkin Yayıncılık.

Haspelmath, Martin (2002). Understanding Morphology. London: Arnold.

Haspelmath, Martin and Balthasar Bickel (2008). "The Leipzig Glossing Rules: Conventions for interlinear morpheme-by-morpheme glosses". Leipzig. Retrieved January, 28, 2010.

Herin, Bruno (2012). “The Domari language of Aleppo (Syria)”. Linguistic Discovery 12/2: 1-52.

Herin, Bruno (2015). "Domari: The Language of the Middle Eastern Gypsies". The Middle East in London, 11 (5): 15-16.

Herin, Bruno (2016). “Elements of Domari Dialectology", Mediterranean Language Review, 23: 33-73.

Herin, Bruno (2020). "Northern Domari”. Arabic and contact-induced change, Ed. Christopher Lucas, Stefano Manfred, Berlin: Language Science Press, 489-509.

Kenrick, Donald (2007). Historical Dictionary of the Gypsies (Romanies), Second Edition, The Scarecrow Press, Inc. Lanham, Maryland, UK.

Koole, Tom and Jan D. ten Thije (2001). "The reconstruction of intercultural discourse: Methodological considerations", Journal of Pragmatics, Volume 33, Issue 4, 571-587.

Matras, Yaron (2007). A Grammatical Sketch of Domari, School of Languages, Linguistics and Cultures. The University of Manchester.

Matras, Yaron (2012). A Grammar of Domari. Ed. Georg Bossong, Bernard Comrie etc. Berlin/Boston: 
De Gruyter Mouton.

Matras, Yaron (2020). “Jerusalem Domari". In Christopher Lucas and Stefano Manfredi (eds.), Arabic and contact-induced change, Berlin: Language Science Press. 511-531.

Merlini-Barbasei, Lavinia and Wolfgang U Dressler (2020). "Pragmatic explanations in morphology", Word Knowledge and Word Usage, Ed. Vito Pirrelli, Ingo Plag and Wolfgang U. Dressler De Gruyter Mouton, 405-452.

Rüdiger, Johann Christian Christoph (1782). “On the Indic Language and Origin of the Gypsies”, Introduction to Romani Linguistics (LI 7192), Leipzig P.G. Kummer: 37-84.

Spencer, Andrew (1998). "The redundancy of lexical categories". If you see what I mean. Essayson language, presented to Keith Brown on the occasion of his retirement in 1998. Essex Research Reports in Linguistics, Special Issue, 14-33.

Thije, Jan ten. Jochen Rehbein and Anna Verschik (2012). "Receptive multilingualism introduction", International Journal of Bilingualism, 16 (3): 245-247.

Thomason, Sarah Grey (2001). Language Contact. Edinburgh: Edinburgh University Press.

Uçar, Aygül. (2008). Eylemde Çokanlamlılık ve Sözlük Girdisi Olarak Katkısız Eylemler [Polysemy and Light Verbs as Dictionary Entries]. XXI. Ulusal Dilbilim Kurultayı Bildirileri, Mersin, 137145.

Varol, Orhan (2017). “Türkçenin \{-mIş\} Yapısının Kürtçe-Türkçe İki dillilerin Sözcelerindeki İşlevsel ve Kullanımsal Farklılıkları", [Functional And Pragmatic Differences of Turkish \{mIş\} Construction in the Utterances of Kurdish-Turkish Bılınguals]. Ressjournal. (19): 271-284.

Varol, Orhan (2019). “Tehlikedeki Doğu Anadolu Domcası: Dilsel Etkileşim ve Birinci Dilde Gerileyici Çok dillilik", [Endangered Eastern Anatolian Domani: Language Contact and Recessive Multilingualism in Mother Tongue],Dilbilimde Güncel Tartışmalar. ed. Kamil İşeri. Ankara: Dilbilim Derneği Yayınları:59-75.

Varol, Orhan (2020). “Tehlikedeki / Gizli Dil Domani Sözcük Listesi Üzerine Bir Çalışma”, [A Study on Word List of Endangered / Secret Domani Language], Uluslararası Dil Edebiyat ve Kültür Araştırmalan Dergisi, 3 (2) , 206-222.

Wit, Erns-Jan Camiel and Marie Gillette (2013). What is Linguistic Redundancy. https://www.math.rug.nl/ ernst/linguistics/redundancy3.pdf. Accessed: 11 June 2021.

\section{ABBREVIATIONS}

$\begin{array}{llll}1,2,3 & \text { 1st, 2nd, 3rd person } & \text { OPT } & \text { Optative } \\ \text { COP } & \text { Copular } & \text { P } & \text { Plural } \\ \text { CMP } & \text { Comparative } & \text { POSTP } & \text { Postposition } \\ \text { DIR } & \text { Direct Case } & \text { PREP } & \text { Preposition } \\ \text { EXS } & \text { Existence } & \text { PRES } & \text { Present } \\ \text { IMP } & \text { Imperative } & \text { PPRT } & \text { Past Participle } \\ \text { IPA } & \text { International Phonetic Alphabet } & \text { PROG } & \text { Progressive } \\ \text { IRR } & \text { Irrealist } & \text { PRS } & \text { Present } \\ \text { IZ } & \text { Izafe } & \text { PST } & \text { Past } \\ \text { LOC } & \text { Locative } & \text { RFL } & \text { Reflexive } \\ \text { OBL } & \text { Oblique Case } & \text { S } & \text { Singular }\end{array}$


